\title{
REGULATION OF
} CAPITAL ADEQUACY IN WESTERN EUROPEAN BANKING THROUGH THE INTERNAL CAPITAL ADEQUACY ASSESSMENT PROCESS (ICAAP) \& THE SUPERVISORY REVIEW \& EVALUATION PROCESS (SREP)

THOMAS DRAPER

The regulation of capital adequacy within Europe is complex and has only recently started to become coordinated. This paper will first define the European legislation which controls such national regulation and then specifically analyse the functioning of the Internal Capital Adequacy Assessment Process (ICAAP) and the Supervisory Review and Evaluation Process (SREP) in the largest Western European economies. The specific enforcement regime of the SREP is usually left up to national regulators, and thus the 'main focus' of the SREP in each country will be elucidated with the methodology used in each country explained in "Methodological Focus Areas". The countries examined are: Austria, Belgium, France, Germany, Iceland, Ireland, Italy, Luxembourg, the Netherlands, Spain, Switzerland, and the United Kingdom. Conclusions will then be drawn as to the differences in the approaches, and the efficacy of the regulation and the implications for an integrated international enforcement system will be discussed. 


\section{INTERNATIONAL STANDARDS ON BUSINESS AND HUMAN RIGHTS}

At its core, the form and role of regulation in Europe is governed by the Basel agreements (Basel.int, 2014). There is, however, a wide variation of enforcement programmes and detailed methodologies. The overall agreement is based on membership of the Financial Stability Board (FSB) and adoption of the Basel Accords. The European Union has also adopted legislation, a Capital Requirements Directive (the current update is known as CRD 4) from Directive 2013/36/EU, and a set of Capital Requirements Regulations (CRR) from Regulation 575/2013 (Europa.eu, 2014). Precise methodologies of the measurement of risk-based assets vary, and these are examined for each country. Specifics can sometimes be closely guarded; Italy, for example, uses an algorithm to measure aspects of capital adequacy, the precise nature of which remains obscure.

\section{THE FUNCTIONING OF ICAAP AND SREP IN INDIVIDUAL COUNTRIES}

\section{AUSTRIA}

The banking market in Austria is broken down into three sectors: savings, private, and cooperative banking. Erste Bank, UniCredit Bank Austria, and Raiffeisen Zentralbank are the three largest banks in the country. UniCredit Bank Austria is a subsidiary of Italy's UniCredit Group. Austrian banks must conduct an Internal Capital Adequacy Assessment Process (ICAAP) as required by the Austrian Banking Act (BWG) under articles 39 and 39a in cooperation with the Österreichische Nationalbank (OeNB). FMA (Österreichische Finanzmarktaufsicht), Austria's financial supervisory authority, also published guidelines. While these guidelines ('Guidelines for Bank-Wide Risk Management', 2006) are not formal requirements, they do factor in FMA's assessment of a bank's ICAAP (Woschnagg, 2008).

\section{INTERNAL CAPITAL ADEQUACY ASSESSMENT PROCESS AT AUSTRIAN BANKS}

The FMA has defined several different ICAAP approaches that banks may use: the 'going concern' approach, the 'gone concern' approach, and a capital planning stage. Banks should apply at least two of these approaches in parallel (Basel.Int., 2014).

The goal of a 'going concern' approach is to make sure there is enough regulatory capital on hand so that business can continue even during a global recession. The primary goal of a 'gone concern' approach, on the other hand, is to protect creditors and a bank's ability to repay debts and deposits regardless of the economic environment. The 'going concern' will thus come to the fore when conducting what under the Basel III agreement are known as 'stress tests'. Such tests are the ability of a bank to repay a specified number of creditors and meet other obligations over a specified period of defined financial adversity. Most large banks will generally turn to economic capital models when calculating their required capital. Under a gone concern approach, many banks will typically use a value-at-risk method at a 99.9 percent confidence level over a one-year time frame. It is up to banks to define available cash resources in a gone concern approach, and definitions vary widely. Many large banks will typically compare their capital to the current value of their equity and subordinated liabilities. Meanwhile, the confidence level used with a going concern approach is lower, generally between 95 and 99 percent over a one-year time frame. Available cash resources may include a bank's excess capital reserves and projected earnings. Results derived at higher confidence levels, between 70 and 90 percent, for example, with a three-year planning horizon, can sometimes be complemented by a third capital planning stage. This can be seen as an early warning sign.

None of the approaches discussed above generally recognise diversification benefits, not even at larger banks. Semi-annual stress tests are conducted by OeNB. As part of the ICAAP framework, Austrian banks are required to update their stress tests and conduct internal stress scenarios, for example, macro-economic stress scenarios. 


\section{BELGIUM}

Belgium's two largest financial conglomerates, KBC and Dexia, offer banking and insurance services. The local subsidiary of ING Group, with more than 100 billion Euros, is also a dominant player in the Belgian financial market. The country's supervisory authority, CBFA (Commissie voor het Bank-, Financie- en Assurantiewezen), outlined the ICAAP implementation process in Title VII of a decree issued in October 2006, which was published in the Belgisch Staatsblad/Moniteur Belge. Additional information regarding banks' ICAPP framework can be found in Circulaire PPB-2007-15-CPB-CPA. The focus areas of CBFA's 2008-2009 ICAAP review of the banking sector are detailed in its annual report for that time period. The supervisory architecture for the financial sector in Belgium was changed by the law of 2 July 2010. The legislature opted to move towards a bipartite supervisory model known as 'Twin Peaks' which was implemented from 1 April 2011. It is organised as follows:

- The National Bank of Belgium, in addition to its mandate of guaranteeing the macroeconomic stability of the financial system, became responsible for the individual prudential supervision of the majority of financial institutions (micro-prudential supervision).

- The Financial Services and Markets Authority (FSMA), the successor to the CBFA, gained a more robust role in the supervision of the rules of conduct applicable to financial institutions, in order to ensure that all clients are treated honestly, fairly and professionally (Cbfa.be, 2014).

\section{INTERNAL CAPITAL ADEQUACY ASSESSMENT PROCESS AT BELGIAN BANKS}

ICAAP approaches in the Belgian banking sector are wide ranging. The approach depends on a bank's size, relevance and services (Kpmg.at, 2014a). Banks usually focus on regulatory capital when considering available financial resources. Larger banks, however, may also look at regulatory capital adjustments, especially if some components under stressed conditions are no longer available. These could include a decrease in goodwill, deferred tax assets, and unrealised losses. The banks could choose to implement a couple of these adjustments under Pillar 1 of Basel III.

Pillar 2 risks are covered by regulatory own funds. Large banks may use an economic capital model to measure these risks. To calculate how much capital they need, many of the country's larger banks will estimate their unexpected losses at a fair value, generally above a 99.9 percent confidence level. This is usually connected to their target rating. In addition to standard risk categories, including credit, operational, concentration and interest rate risks, there are two other economic capital models that also include other risk categories, such as credit spread and funding cost risks. This is a benefit for banks, as it is recommended they measure all material risks. Many banks will also usually examine the impacts of diversification effects when calculating economic capital. Banks, however, do not appear to be evaluating risks facing their economic capital, including strategy and liquidity risks. Instead, they are putting together contingency plans and management frameworks to help combat these risks (Google books, 2014b).

\section{THE OVERALL ORGANISATION OF THE SUPERVISORY REVIEW \& EVALUATION PROCESS}

Banks operating on the Belgian market are expected to submit an information file to FSMA detailing their ICAAP approach. The file, which is not predefined by the supervisory authority, lays the foundation for the FSMA review. The file should include an overview of the bank's basic risks and an explanation as to why it selects these risks to hold capital against. The file should also include internal audit reports on the ICAAP assessment and Pillar 2 validation reports (Belgium Detailed Assessment of Compliance with the Basel Core Principles for Effective Banking Supervision, 2014a). FSMA auditors conduct on-site visits as part of their review of a bank's ICAAP submission. FSMA also schedules regular meetings with the bank's top managers to discuss its ICAAP (Belgium Detailed Assessment of Compliance with the Basel Core Principles for Effective Banking Supervision, 2014b). 
FSMA discusses its ICAAP review with the bank's top managers. It also puts its findings, including observations of the bank's risk management and issues related to the ICAAP methodology, in a written report (Belgium Detaled Assessment of Compliance with the Basel Core Principles of Effective Banking Supervision, 2014c).

\section{SREP: MAIN FOCUS}

The scope of FSMA's supervisory review, according to the proportionality principle, is based on the size and relevance of each bank. A Belgian bank's ICAAP framework must be holistic and consistent. It should be based on a stressed capital plan that is forward-thinking. The plan should define the bank's risk appetite and risk policies as well as outline its management measures and contingency plans. A bank must prove that its risk management methodologies are useful and accurately reflect the bank's risk profile (Kpmg.at, 2014b).

A bank's internal Pillar 2 models and ICAAP framework are factored into its ICAAP score card by the FSMA. The supervisory review scores the quality of a bank's ICAAP approach and control functions as well as its internal management, risk management, shareholder support and relevance. The bank does not see its final score. Instead, the bank is told how much own funds it is required to have, which is then compared with the bank's internal calculations.

The FSMA assessment provides recommendations on ways a bank can improve its ICAAP methodologies. However, SREP does not just end with a list of recommendations. It is a continuous process. Banks respond to FSMA's report with additional information related to its ICAAP methodologies. Action plans addressing the critical points of a FSMA report may be put into place. Banks may also send in regular progress reports (Kpmg.at, 2014c). Banks may be forced to comply with Pillar 2 adjustments if they fail to have the required level of own funds. (This is based on Article 136 of the CRD.) However, such capital add-ons are seen as a last resort and should only be considered if all other measures have failed.

\section{SREP: METHODOLOGICAL FOCUS AREAS}

FSMA's primary focus when conducting an ICAAP assessment is the methodologies used in a bank's ICAAP framework. The methodologies should be sufficient, and the framework should be consistent. Banks identify available financial resources based on an economic concept where only stressed capital can be considered. During its ICAAP review, FSMA makes sure to address necessary regulatory own funds adjustments. These can include unrealised losses, deferred tax assets, and a decrease of goodwill.

FSMA requires banks to identify, measure and manage all their material risks. These may include funding cost risks, pension risks and migration and spread risks. Banks are responsible for defining their material risks. A bank must prove its ICAAP framework is sound and functional. The framework must include a management risk assessment, an internal audit of ICAAP methodologies and comprehensive stress testing procedures.

\section{The stress tests must cover a range of scenarios. Banks should routinely analyse their capital needs and resources to ensure they can meet their capital requirements should a macro-economic shift lead to a crippling recession.}

If a bank plans on taking management action to decrease its capital needs, then its stress tests should consider the potential challenges of this action. If a bank's ICAAP analysis takes diversification effects into account, then they, too, should be subjected to a stress test. These could involve, for example, inter-risk correlations or diversification between subsidiaries. 


\section{FRANCE}

There are four dominant banking groups in France: Société Générale, BNP Paribas, Crédit Agricole, Banque Populaire and Caisse d'Epargne (BPCE). The Autorité de Contrôle Prudentiel (ACP), the country's financial supervisory authority, outlined its ICAAP requirements in 'Implementation of the Supervisory Review and Evaluation Process (Pillar 2) - Criteria and Methodology Used by the Commission Bancaire' (December, 2006). Annual Report Commission Bancaire (2007) also provides more information about the ICAAP process (Acpr.banque-farance.fr, 2014a). The ACP guidelines are similar to the rules followed by the Committee of European Banking Supervisors (CEBS).

\section{INTERNAL CAPITAL ADEQUACY ASSESSMENT PROCESS AT FRENCH BANKS}

French banks use a wide variety of ICAAP methods. Most will start with the regulatory capital requirements addressed in Pillar 1 before moving on to the requirements outlined in Pillar 2. A bank may consider additional add-ons for risks not covered in Pillar 1. These may include concentration and interest rate risks. Large banks will apply various models before deciding on the add-ons. This could include an economic capital model at a confidence level of at least 99.9 percent. A bank will usually also assess its capital requirements using macro-economic stress scenarios and add a buffer to the capital demand in Pillar 2. Buffers could also be identified for risks that are difficult to quantify, including strategic, reputation, and liquidity risks (www.Kpmg.at, 2014d). The effectiveness with which a bank integrates ICAAP methods into its management systems is taken into consideration by ACP during the supervisory review and evaluation process.

\section{THE OVERALL ORGANISATION OF THE SUPERVISORY REVIEW \& EVALUATION PROCESS}

ACP will generally review a bank's ICAAP structure on an annual basis. The process involves qualitative and quantitative information, some of which must be provided by the bank. This information includes accounting data, annual financial reports, internal documents, outside audit reviews, and data collected during senior management meetings. A bank is assigned a risk classification based on its overall SREP score, which incorporate its ICAAP results. While each bank's SREP review follows a similar framework, the methods used may differ depending on a bank's size, relevance, and complexity.

\section{SREP: MAIN FOCUS}

ACP evaluates quantitative and qualitative data when assessing a French bank's ICAAP framework. It considers potential risks the bank may face as well as its internal monitoring and control systems. Aspects of the bank's ICAAP framework are usually compared with other French lenders' ICAAP approaches. CEBS best-practice recommendations also factor into the review process.

Best-practice models for risk management, based on a bank's business model, are formed during the review and evaluation process. SREP feedback will differ depending on a bank's overall results. ACP will evaluate the quality of the bank's risk management systems and provide detailed recommendations on how to improve. The regulator's feedback might also include guidance related to Tier 1 capital targets. The French regulator does not disclose either its SREP scoring system or Tier 1 capital targets. However, market analysts speculate that Tier 1 capital ratios for large financial groups operating in France would range between upper and lower single-digit percentages (Acpr.banque-france.fr, 2014b).

\section{If ACP observes serious problems with a bank's internal control, compliance or risk management systems during its review, the regulator may choose to publicly report its findings.}

If the regulator feels corrective measures would not be effective, it may impose a supplementary capital requirement (Acpr.banque-france.fr, 2014c). 


\section{SREP: METHODOLOGICAL FOCUS AREAS}

A bank's management team is responsible for the ICAAP framework and implementation. Internal capital management should be a central factor of the bank's risk assessment strategies. The main focus of the regulatory off-site review is to make sure the bank is in compliance with liquidity, solvency, and management ratios. ACP will also analyse additional quantitative information during its off-site review. This analysis will take several qualitative factors into consideration, including the bank's day-to-day income and profits, regulatory capital, corporate governance strategies, and internal control systems, particularly in regards to risk monitoring, money laundering, and terrorist financing. ACP stresses the importance of monitoring available capital resources, specifically minority interests and hybrid capital tools. To that end, the regulator intends to regulate capital resources. A bank should pair its ICAAP assessment with a forward-thinking capital plan that reflects its long-term business strategies. The bank can apply, for example, a stress test to measure what kind of impact changes to the financial environment could potentially have on business (Acpr.banque-france.fr, 2014d).

\section{GERMANY}

The German financial market is broken down into private, savings and cooperative banking. Deutsche Bank is the leading lender, followed by closely by Commerzbank. There are also numerous other banks operating on the market, including Landesbanken (savings) and DZ Bank and WGZ Bank (cooperative). BaFin, the federal financial supervisory authority, outlines ICAAP regulations using a principles-based approach under its risk management (MaRisk) guidelines (Circular, 11/2010). Banks operating on the German market must abide by the country's bank act, Kreditwesengesetz (KWG), which introduced Pillar 2 of Basel II into law (Bafin.de, 2014a).

\section{INTERNAL CAPITAL ADEQUACY ASSESSMENT PROCESS AT GERMAN BANKS}

Most banks will either use a 'going concern' or 'gone concern' approach when implementing their ICAAP. Larger banks seem to favour a 'gone concern' approach; however, they will also apply a 'going concern' approach as an auxiliary measure to better assess their capital reserves. The goal of a 'going concern' approach is to make sure there is enough regulatory capital on hand so that business can continue even during a global recession. The primary goal of a 'gone concern' approach, on the other hand, is to protect creditors and a bank's ability to repay debts and deposits regardless of the economic environment. A bank's available capital resources and required capital would differ depending on which approach is used.

\section{'GONE CONCERN' ICAAP APPROACH}

A 'gone concern' approach is usually centred on an economic capital model. A bank will typically use a valueat-risk method at a 99.9 percent confidence level over a one-year time frame to calculate its economic capital. It is up to banks to define available cash resources in a 'gone concern' approach, and definitions vary widely. Many banks will typically compare their capital to the current value of their equity, hybrid capital, and subordinated liabilities. Adjustments may be made to simulate the capital situation a bank may face following an economic meltdown. Such adjustments may include a decrease of minority shares, deferred tax assets, or goodwill. Banks may also choose to adjust unrealised gains or losses, such as loans and customer deposits. It is not uncommon for banks to use stress tests during their ICAAP assessment to simulate a serious financial downturn. Many banks use the results from these tests to better assess their capital adequacy levels.

\section{'GOING CONCERN' ICAAP APPROACH}

Aspects of a 'going concern' approach are similar to a gone concern approach. The confidence level used to calculate economic capital in a 'going concern' approach; however, it is lower, generally between 95 and 99 percent. This helps banks pinpoint potential future losses. A bank's objective is to ensure it has sufficient capital resources available for business to continue in the event of a serious economic meltdown. Banks will generally factor in regulatory own funds. Adjustments may be applied to take future profits into consideration. Stress tests are normally used in a 'going concern' approach. 
THE OVERALL ORGANISATION OF THE SUPERVISORY REVIEW \& EVALUATION PROCESS

BaFin conducts the supervisory review and evaluation process in partnership with the German central bank (Deutsche Bundesbank). While the financial regulator oversees the assessment process, the central bank is in charge of monitoring the lenders on a regular basis. The Deutsche Bundesbank will report its findings to BaFin, which will impose any necessary corrective measures (agm.db.com, 2014). In order to effectively monitor the country's financial sector, the Deutsche Bundesbank requires banks to disclose their annual financial and external audit reports, as well as any pertinent quantitative information. The Deutsche Bundesbank will also meet regularly with a bank's senior managers. BaFin may require the central bank to conduct further on-site reviews in accordance with section 44 of the country's bank act. These additional reviews will depend on a bank's size and complexity, but typically take place every few years. BaFin may also request an additional on-site review to clarify any observations or questions raised during the review process.

\section{SREP: MAIN FOCUS}

The main focus of the supervisory review and evaluation process is to assess how a bank could impact the German financial sector if its risk management and profile are not up to standards. The review process, specifically in regards to a bank's ICAAP assessment, has become more rigorous since 2010. Most large banks are subjected to at least one on-site ICAAP review a year. A bank will be rated based on the assessment results, which will determine how much supervision that bank will need in the future. The results will also include observations about the bank's risk management process. Regulators will scrutinise the bank's ICAAP approach and methodologies. BaFin will either accept the bank's ICAAP or require certain adjustments be applied to the approach. BaFin will only hand down specific capital guidance in atypical situations.

\section{SREP: METHODOLOGICAL FOCUS AREAS}

BaFin and the Deutsche Bundesbank outlined methodological focus areas of the ICAAP assessment in November 2010. The focus areas are consistent with descriptions large banks have given about the regulatory process. When applying a gone concern approach, banks need to evaluate all their economic risks. These generally will include Pillar 2 risks, such as interest rate, concentration, business, pension, and credit spread risks. The methodological focus areas for the gone concern approach should also address banks' available financial resources. Banks need to consider how a sudden serious loss might impact their capital resources and plan accordingly. A loss can impact, for example, potential future profits, minority shares, net deferred tax assets, unrealised losses, and goodwill. In addition to these focus areas, German financial regulators will also evaluate the management and integration quality of a bank's overall ICAAP framework (Bafin.de, 2014b).

\section{ICELAND}

This small nation has recently become involved more closely with the European Union after its bankuptcy and bailout.

\section{INTERNAL CAPITAL ADEQUACY ASSESSMENT PROCESS AT ICELANDIC BANKS}

Since the IMF involvement in the Icelandic economy, provisions for ICAAP and SREP have been made. The CRD IV rules are followed. The ICAAP is a matter for individual banks with the SREP undertaken by the Financial Supervisory Authority (FME)

\section{SREP: MAIN FOCUS}

The main focus is to ensure that each bank is adequately capitalised and has a loan to capital ratio that accords to Basel 3 principles. There is still uncertainty in the face of Supreme Court rulings on foreign exchange-indexed loans and what risk weighting should be applied to these and other sets of assets.. Maintaining a strong, independent, and adequately resourced Financial Supervisory Authority (FME) is considered essential for effective financial sector oversight (Sedlabanki.is, 2014). 


\section{SREP: METHODOLOGICAL FOCUS AREAS}

Iceland has adopted, or is in the process of adopting, ICAAP and SREP according to CRDIV and CRR. The focus is on detailed analysis of the Pillar 2 areas of Basel 3. Counterparty risks of other banks are also fully explored. The main banks are in the process of being recapitalised which sometimes makes the Capital Adequacy Ratio complex to compute.

\section{IRELAND}

There are a surprisingly large number of World and European banks registered in Ireland due to its low partial rate of taxation.

\section{INTERNAL CAPITAL ADEQUACY ASSESSMENT PROCESS AT IRISH BANKS}

Ireland observes the current CRD IV rules and requires an ICAAP of all institutions currently trading as banks in The Republic. The ICAAP must clearly state all relevant ratios according to the directive and is enforced through the Capital Requirement Regulations. These are expected to be clearly stated in the same template as all other European countries (Google Books, 2014c)

\section{SREP: MAIN FOCUS}

The main focus of the supervisory review and evaluation process is to assess how a bank could impact the Irish financial sector if its risk management and profile are not up to standards. The review process, specifically in regards to a bank's ICAAP assessment, has become more rigorous since 2010-2011. Most large banks are subjected to at least one on-site ICAAP review a year. The bank of Ireland may at any time use its executive powers to increase any capital ratio on any bank to a level it regards as reasonable. Furthermore, any bank will be rated based on the assessment results, which will determine how much supervision that bank will need in the future, based on previous ICAAP results. The results will also include observations about the bank's risk management process, and fully coordinate with European and international regulators (Google Books, 2014c).

\section{SREP: METHODOLOGICAL FOCUS AREAS}

An ICAAP Review is conducted annually for all credit institutions. For high impact firms and all other firms subject to a full risk assessment in any given year an in-depth review is carried out. This is a full review of the ICAAP as updated and submitted by the firm. The review of the ICAAP will be influential in preparing the supervisory engagement plan for the year and the review in conjunction with other engagement tasks ensures that the supervisors can determine the adequacy of the outcome of the ICAAP (capital number) in addition to also assessing the following: 1) the extent to which the subject institution's board and senior management have taken responsibility for the ICAAP, 2) the extent to which the design of the ICAAP has been fully specified and documented the extent to which the ICAAP is used to inform decision-making (the use test), 3) the extent to which the ICAAP is risk-based, 4) the extent to which the ICAAP is reviewed, 5) the comprehensiveness of the coverage of the ICAAP, and 6) the adequacy of measurement and assessment processes. For banks that are not high impact and are not subject to a full risk assessment in any given year a less granular assessment of the ICAAP is taken, with less individual areas assessed (bankofireland.ie, 2014).

\section{ITALY}

UniCredit Group and Intesa Sanpaolo dominate the Italian banking market, followed by Banca Monte dei Paschi, Banco Popolare and UBI Banca. At the end of 2009, these banks' balance sheets topped 100 billion Euros. The Bank of Italy (Banca d'Italia, also known as Bankitalia) outlined the country's new implementation process for SREP and Pillar 2 of Basel II in 'New Regulations for the Prudential Supervision of Banks' (Circular 263, December, 2010). More information about the ICAPP can be found in the 'Guide to Supervisory Activities' (Circular 269, May, 2008). 


\section{INTERNAL CAPITAL ADEQUACY ASSESSMENT PROCESS AT ITALIAN BANKS}

ICAAP approaches vary depending on the complexity of the bank. Larger Italian banks, for instance, favor economic capital models, which they use to measure their risk profile. This covers Pillar 1 risks, including credit, operational and market risks as well as interest rate risk, real estate risk, participation risk and business risk. Diverse approaches are used to identify available financial resources. The typical starting point is regulatory own funds. However, each bank's adjustments will vary. These adjustments could include future or unrealised profits, goodwill, and losses (Bafin.de, 2014b). Banks will apply stress tests to their capital adequacy evaluations. They might also use other capital buffers to study the impact of different stress scenarios. Buffers can be defined for each risk category, for example, model risk.

\section{THE OVERALL ORGANISATION OF THE SUPERVISORY REVIEW \& EVALUATION PROCESS}

An algorithm based on prudential returns is used to assess a bank's profit, risk exposure, and capital adequacy. The algorithm is able to generate an automatic score. If necessary, the regulator will outline a corrective action plan a bank must implement if its ICAAP score is not up to par. A bank's ICAAP approaches are reviewed during the Supervisory Review and Evaluation Process. Risk areas, such as profitability, capital adequacy, governance and control systems, are assessed by the Bank of Italy annually. A bank must submit a report detailing its ICAAP framework. This should include methodologies and risk appetite as well as an internal ICAAP review, pinpointing any weaknesses and necessary corrective measures. Information provided in a bank's ICAAP report will depend on the business services it provides to clients. Additional information related to a bank's ICAAP framework can be collected during off-site document reviews. Such documents may include internal supervisory and audit reports and financial statements.

The Bank of Italy now conducts on-site reviews and meets regularly with banks' top managers about issues related to the ICAAP. While banks must assess and disclose their capital adequacy levels to the Bank of Italy on an annual basis, it is strongly recommended that they perform internal ICAAP assessments regularly throughout the year. It is up to each bank to decide how often they conduct this assessment based on the methodologies they apply and the risks involved (Imf.org, 2014a).

\section{SREP: MAIN FOCUS}

Large Italian banks are expected to apply advanced methodologies during their ICAAP assessments. There are currently no other specific target areas of the SREP process. While the Italian SREP currently does not have any other specific requirements, it is likely that the Bank of Italy will at some point in the future increase on-site ICAAP reviews (Imf.org, 2014b).

\section{LUXEMBOURG}

There are more than 100 banks registered in Luxembourg however only a few are local banks; the rest are affiliates of foreign financial groups which adhere to the capital requirements of their respective parent companies. The country's financial regulator, the Commission de Surveillance du Secteur Financier (CSSF), has published its own ICAAP implementation requirements (Circular 301/2007). The requirements were updated in Circular 338/2008 in regards to stress tests for interest rate risks and again in Circular 403/2009 in regards to liquidity risk. A detailed study was carried out into the impacts of the liquidity ratios in 2011 (Cssf.lu, 2014a).

\section{INTERNAL CAPITAL ADEQUACY ASSESSMENT PROCESS AT LUXEMBOURG BANKS}

ICAAP approaches used in the Luxembourg banking sector are wide ranging. Most banks, though, keep their approaches simple, mainly sticking to Pillar 1 capital requirements. Pillar 2 risks, meanwhile, apply capital buffers. The size of the buffer is calculated by qualitative formulas. To that end, a bank's risk capacity would be based on its regulatory own funds (Kpmg.at, 2014d). A few banks will use more advanced ICAAP approaches, for instance economic capital models, which can show the effects of diversification in 
various risk categories. A few banks will chose to incorporate additional measures into their risk-taking strategy, such as future profits and losses. ICAAP results are submitted to top managers and must be approved by the bank's executive board. In accordance with regulatory requirements, banks will generally conduct an internal audit of their ICAAP assessment.

\section{THE OVERALL ORGANISATION OF THE SUPERVISORY REVIEW \& EVALUATION PROCESS}

CSSF will review a bank's ICAAP at least once a year. The frequency depends on the bank's size and standing or if the bank has recently reported any strategic or economic changes. Banks must send an ICAAP report to CSSF. The report should include an outline of the bank's ICAAP structure and its current and future risk profile. It should also discuss the effect its capital planning may have on its financial resources (PwC.lu, 2014). An outside auditor will review a bank's ICAAP. The long form audit will include a review of the bank's risk management. The auditor will also evaluate whether the bank is complying with regulatory requirements. A copy of the audit report will be submitted to CSSF. A bank's internal and external audits will have a strong impact on the final review conducted by CSSF. The regulator may also take into account additional data provided by the bank, meetings it conducts with bank managers and on-site audits. Discussions held between CSSF personnel and bank managers play an important role in the supervisory review process. The findings reported in an external or internal audit or in a CSSF report are thoroughly examined by a bank's top managers. Banks are required to implement any corrective measures outlined in the reports. CSSF will follow up and make sure the banks are in compliance. CSSF is allowed to impose stricter regulatory measure on banks at its discretion. For example, a bank may be required to increase its capital levels above the regulatory minimum. Its services or operations may be curtailed or its risk profile lowered (Cssf.lu, 2014b).

\section{SREP: MAIN FOCUS}

The CSSF applies a diverse approach to its review and evaluation of the country's banking sector. It assesses all data available, including quantitative and qualitative data. ICAAP is considered an internal process; therefore, banks are allowed to use different implementation approaches. The final report, which should include qualitative data, must show that the bank has enough capital in its reserves. Given Luxembourg's diverse regulatory makeup, market analysts believe regulators, including CSSF, will put increasing pressure on banks to improve their ICAAP approaches. The emphasis will be on economic capital models, inside of buffers.

\section{SREP: METHODOLOGICAL FOCUS AREAS}

As there is a high number of fund managers operating within the country, Luxembourg regulators pay particular attention to risks associated with wealth management. These include legal, reputational, and operational risks. Private banking is paramount in Luxembourg. Wealth management aside, the primary focus of CSSF audits is interest rate and concentration risks.

In order to measure total risk during the assessment process, CSSF will examine the effects that intra- and inter-risk categories have on each other. It will also look at the effects of mitigation, which is normally not permitted when calculating adequate own funds. Since there is a lack of available market data, correlation assumptions are, for the most part, based on estimates (Putnis, 2014, pp. 514-533).

\section{THE NETHERLANDS}

The Dutch banking sector is dominated by Rabobank, ING and ABN Amro. SNS REAAL, which has a balance sheet of more than 100 billion Euros, is also active in the Netherlands. Policy Rule on Principles for the Implementation of Pillar 2 of the Basel II Capital Accord, published in 2007, outlines the country's ICAAP requirements. In this publication, De Nederlandsche Bank (DNB) lists the ICAAP guidelines banks must use as well as the primary criteria evaluated during the review process. The publication also addresses confidence levels, diversification effects, and the ICAAP time frame. In addition, it lists the data banks need to provide to the regulator. 


\section{INTERNAL CAPITAL ADEQUACY ASSESSMENT PROCESS AT DUTCH BANKS}

A bank's ICAAP approach will depend on its size and complexity. Large banks tend to use Advanced-IRB for the Pillar 1 assessment. They will use the AMA approach for operational and credit risks, while for market risks, they generally use internal model approaches. When conducting the Pillar 2 assessment, large banks prefer to use economic capital approaches (Kpmg.at, 2014f, pp. 26-27). A bank will usually take diversification effects into consideration when calculating the contributions of various risk types. With the exception of Pillar 1 and interest rate risks, banks are allowed to apply add-ons or buffers to other types of risks. These can include pension, business model, funding, and concentration risks. In an effort to be more forward-thinking about capital resources, banks will apply business planning assumptions to their ICAPP assessments. Banks will incorporate results of their top-down stress tests, which should include internal as well as macro-economic tests, into their ICAPP approach to help calculate capital adequacy levels. Banks must use macro-stress scenarios that have been approved by DNB.

\section{THE OVERALL ORGANISATION OF THE SUPERVISORY REVIEW \& EVALUATION PROCESS}

Banks must file regular reports with DNB, which are taken into account during the supervisory review process. The report must include qualitative and quantitative data. Qualitative data would detail, for example, the ICAAP setup and how the process would be implemented into the bank's management systems. Quantitative data, meanwhile, would cover stress testing and risk measurement and identification. Banks must also outline the difference between Pillar 1 and Pillar 2 capital (Db.nl, 2014a).

DNB will audit a bank's ICAAP approach and capital during its yearly review and evaluation. The regulator will then review the bank's capital adequacy. This second step also takes into account the bank's 'SREP capital'. In order to compare the capital requirements defined under Pillar 1 and Pillar 2, DNB will apply a 99.9 percent confidence level to a one-year time frame. It will also review the capital requirements at other banks. This process helps DNB set a target capital level, which is reviewed by bank management. DNB submits a report to the bank that outlines its ICAAP findings and may include corrective measures the bank is expected to implement within a certain time frame. Corrective measures could surround capital calculations related to various risks and capital management. The DNB report might also find fault with a bank's assessment of Pillar 2 risks or other risks factors considered important under Pillar 2. Capital addons could be used to boost Pillar 1 capital if DNB determines its capital target level is greater than a bank's own calculation. These add-ons, considered corrective measures, may be temporary or permanent.

\section{SREP: MAIN FOCUS}

A bank's ICAAP approach must be in line with CEBS guidelines related to stress tests, interest rate risks, ICAAP, and concentration risks. DNB supports these guidelines. A bank's size and complexity should be taken into consideration before ICAAP methods are applied. DNB suggests large banks calculate how much ICAAP capital they will need using an economic capital model (Dub.nl, 2014b)

Banks should take several things into consideration when coming up with their ICAAP framework, which must cover material risks lenders face on the Dutch market. Banks must thoroughly analyse Pillar 1 and Pillar 2 risks to determine how they might impact business. Pillar 1 risks include operational, market and credit risks, while Pillar 2 risks cover interest rate, pension, reputational, and concentration risks. Future capital adequacy must also be analysed and stress tests should be applied to assess capital adequacy in different scenarios. A contingency plan should be prepared. Finally, a bank's ICAAP framework must adhere to its business strategy. Therefore, changes in services that could impact capital resources must be addressed (Dub.nl, 2014c). Most large Dutch banks rely on state support, which is why DNB stresses the importance of maintaining adequate capital levels and adding more qualitative measures to the ICAAP framework. These can include the stability of a bank's business model and quality risk management procedures. 


\section{SPAIN}

Santander Group and Banco Bilbao Vizcaya Argentaria (BBVA) are two of Spain's biggest commercial banks, while Caja Madrid and La Caixa are the sector's biggest savings banks. Mortgage loans are also big market drivers. Banco de España (Bank of Spain) is the country's financial regulator. It has published guidelines related to ICAAP requirements. The Basel III common equity theory was introduced into the guidelines in January 2011 (Guía del Proceso de Autoevaluación del Capital de las Entidades de Crédito - PAC, 2011). The Bank of Spain's regulatory review process is outlined in Guía del proceso de Revisión del Capital, 2010. Additional capital requirements are also addressed by the Spanish Ministry of Economy in the law 'Real Decreto-ley 2/2011, para el reforzamiento del sistema financier'. The law outlines solvency and minimum capital requirements.

\section{THE 'SPANISH BASEL 2.5'}

Basel 2.5, as the new capital directive is referred to in Spain, requires that banks maintain their minimum common equity at 8 percent. This is a significant increase of Basel II capital levels. Banks that meet certain criteria are required to maintain their minimum common equity at 10 percent. This includes banks that have more than 20 percent of wholesale funding or if less than 20 percent of its capital is not privately owned. The 10 percent requirement generally applies to savings banks (Esrb.europa.eu, 2014).

Under Basel 2.5, the Spanish regulator is permitted to impose high minimum capital levels based on stress test results. The Ministry of Economy looks to Basel III to define common equity. The definition considers several factors, including minority interest, share premiums, disclosed revenues, common shares and retained earnings. It also takes into account AfS adjustments, as well as tools from the Fondo de Reestructuración Ordenada Bancaria. FROB was created by the state to help improve the banking sector's capital levels (Kpmg.at, 2014, p. 29).

The regulator released an extensive report in March 2011 about how well the new capital requirements were being maintained on the market. Banks found to have inadequate capital levels had to submit a plan detailing how they would maintain their capital levels at 8 or 10 percent. Their plans had to be filed with the Bank of Spain by 30 September 2011. Banks whose strategy included a possible stock market listing were given three extra months to turn in their plans (Roldan, 2007).

\section{THE INTERNAL CAPITAL ADEQUACY ASSESSMENT PROCESS AT SPANISH BANKS}

Banks are under increased pressure to maintain adequate capital levels, which is why capital planning is an integral part of the ICAAP assessment. Banks have had to update their strategies to fit new capital regulations, especially those outlined under Pillar 2. To the end, economic capital models will likely become less relevant in the future (Esrb.europa.eu, 2014). Banks use two different approaches to measure risk. Most will use the Bank of Spain's standard approach for measuring Pillar 2 risks, while others, typically larger banks, favour a more advanced economic approach. The more advanced approach examines the benefits of diversification effects.

\section{THE OVERALL ORGANISATION OF THE SUPERVISORY REVIEW \& EVALUATION PROCESS}

Spain's supervisory process has four key focus areas. The Bank of Spain will review a bank's accounting process and make sure it is in compliance with financial regulations. The regulator will also conduct an economic analysis and review the bank's risks and solvency. The review process for most banks includes off-site monitoring and inspection visits. The market's two largest banking groups are also subjected to on-site monitoring. The Spanish regulator will base its review of a bank's ICAAP framework on a wide range of relevant data, including information related to own funds, as well as the internal adequacy assessment report (ICAAR). The regulator will also meet with bank officials in accordance with the on-site inspection plan specified by the ICAAR (Bde.es, 2014). 


\section{SREP: MAIN FOCUS}

Each bank is responsible for designing and implementing an ICAAP framework that best suits its needs. However, the regulator stresses the importance of risk assessment, as well as a capital plan that accurately reflects a bank's core business and risk strategies. Banks are advised to implement their ICAAP into all their control and risk management structures. A bank should also incorporate a capital plan that covers a two- to three-year time frame into its ICCAP. This plan should uphold the Pillar 1 capital requirements as well as the bank's business strategies. The bank must demonstrate in its plan that it has sufficient capital to survive a serious economic meltdown.

A key goal of the supervisory review process is to make sure banks maintain and regularly update their risk profiles, which helps the regulator assess a bank's solvency and predict any future liquidity or profitability issues. Supervisory measures will be determined based on a bank's risk profile. High risk could lead to more supervision if the Bank of Spain deems it necessary (Kpmg.at, 2014, p. 30).

\section{SREP: METHODOLOGICAL FOCUS AREAS}

The Spanish regulator specifically lists what types of capital a bank can use to meet its own funds goal. The Bank of Spain bases its list on Pillar 1 capital resources. The bank should outline its capital plan and own funds goal in its internal adequacy assessment report. The bank needs to show that it has enough capital to meet the regulator's minimum requirements regardless of the economic environment.

When setting its capital goal, the bank needs to take several things into consideration, including the current economic environment, the quality of available capital and possible methods for securing more capital if necessary. Top managers should also review the bank's strategic business plan and risk management and control policies before setting a capital target. The capital plan should be in sync with the bank's strategic business plan. Capital needs identified by stress scenarios should be calculated, and banks should outline possible funding sources for these needs in their ICAAP framework. Funding that is capable of absorbing losses in a stressed economic environment must derive from a going concern approach. Stress scenarios must be adequately severe in order to be useful during the ICAAP process. The regulator may request a bank perform particular stress tests, concerning, for example, GDP reductions, real estate fluctuations and unemployment rates. The regulator can also outline particular scenarios banks should account for during reverse-stress testing (App.bde.es, 2014).

\section{(F) SWITZERLAND}

There are more than 300 banks in Switzerland, a third of which are affiliates of foreign financial entities. The country's leading lenders, however, are UBS and Credit Suisse.

A division of what is now the Swiss Financial Market Supervisory Authority (FINMA) has been overseeing the country's larger banks since 1998. The publication 'Supervision of Large Banks' (Circular 2008/9) outlines special measures related to this task. It addresses a variety of issues, including audits, requirements for reporting and discussion protocol between bank management and the supervisory authority. Basel II requirements were introduced into law in September 2006. The federal ordinance is called 'Capital Adequacy and Risk Diversification for Banks and Securities Dealers'.

\section{THE 'SWISS FINISH'}

In an effort to meet the requirements defined in Pillar 1 of Basel II, FINMA has imposed a buffer that requires banks to increase their net regulatory capital, otherwise known as the 'Swiss finish'. Pillar 1 of Basel II enforces a firm bottom limit in regards to a bank's capital resources. However, this limit can be breached for a short amount of time if related to FINMA's capital buffer. The bank must submit a plan that details how it will maintain an adequate capital level. The plan must be approved by FINMA (Kpmg.at, 2014, p. 32) 
With the exception of the country's two largest lenders, the buffer is equal to 20 percent of a Swiss bank's regulatory capital, according to Pillar 1. The buffer was increased for UBS and Credit Suisse to 100 percent in 2008. The banks needed to maintain this buffer until 2013. The buffer, however, could be lowered to 50 percent during an economic meltdown, but it would need to be brought back up to 100 percent once the crisis passed (Kpmg.at, 2014, p. 32).

A risk-independent leverage ratio was introduced when these new capital requirements hit the Swiss banking sector. The ratio compares a bank's total assets against its core capital. A 3-percent limit was applied to a consolidated level, while a 4-percent limit was applied to an individual level (Kpmg.at, 2014, p. 32). Swiss banks may face other Basel-related adjustments when operating in other countries within Europe. These could include increased asset class weights and capital demands.

\section{INTERNAL CAPITAL ADEQUACY ASSESSMENT PROCESS AT SWISS BANKS}

While FINMA stresses that Pillar 2 is a key factor in a lender's controlling processes and risk management, Swiss banks are ultimately responsible for implementing their own ICAAP structure. In an effort to meet the requirements outlined in Pillar 2, large banks tend to use detailed economic capital models at high confidence levels to simulate unexpected losses. Inter-risk and intra-risk correlation assumptions reflect diversification benefits (Kpmg.at, 2014, p. 32). Banks will, for the most part, base their available financial resources off of their regulatory own funds, which are made up of Tier 1 and bits of Tier 2 capital. A bank will distribute its available financial resources to individual businesses to make sure the ICAAP is properly integrated into its management systems. It will also perform rigorous stress tests to its capital planning (Kpmg.at, 2014, p. 32).

\section{THE OVERALL ORGANISATION OF THE SUPERVISORY REVIEW \& EVALUATION PROCESS}

FINMA will meet periodically with a bank's board of directors and top managers. The supervisory process also includes internal audits and quarterly meetings with outside audit companies. The regulator will conduct yearly on-site reviews. Its findings are outlined in a report and submitted to the management board of the bank. FINMA or an outside auditor will follow up and make sure any corrective measures highlighted in the report have been properly implemented. Outside auditors will also perform more in-depth reviews if requested by FINMA.

\section{SREP: MAIN FOCUS}

Swiss banks are responsible for implementing their own ICAAP framework. However, FINMA stresses the importance of sufficient risk assessment. A bank's capital plan must also be in line with its business and risk strategies. UBS and Credit Suisse are required to maintain acceptable capital planning structures, which must include detailed studies of their capital requirements and outline how they plan to distribute their capital resources.

\section{The banks must show they will be able to sustain their regulatory capital levels throughout the planning stage. To do this, they must evaluate capital demand under normal and stress scenarios, inspired by macro-economic studies by the Swiss National Bank and FINMA.}

The regulator may require further studies to determine, for example, whether certain portfolios or business opportunities may be susceptible to losses (Kpmg.at, 2014, p. 32). The main goal of the SREP process is to establish that UBS and Credit Suisse, in particular, have enough capital to meet the 100-percent requirement under the Pillar 2 add-on. On a wider scale, the process is also used to examine the banks' risk management systems and en sure they can adequately maintain the lenders' risk profiles (Kpmg.at, 2014, p. 33). 


\section{THE UNITED KINGDOM}

The Royal Bank of Scotland, Barclays, Lloyds Banking Group, HSBC, and the Spanish-owned Santander Group control the UK retail and commercial banking markets. There are however a very large number of foreign banks which operate within the United Kingdom, the regulation of which is unclear.

Recently, the UK's chief financial watchdog has sharply tightened its grip on overseas banks that want to take deposits in Britain, pressuring them to open locally regulated subsidiaries with their own access to cash and capital. This is so they could be properly regulated if they operated in the UK.

The FSA's push started in 2008 when the UK government had to step in to protect British depositors in branches of Icelandic banks that collapsed. Its drive has accelerated recently. In September, the FSA announced plans to force non-European Union banks to use subsidiaries if they are from countries such as the US and Australia that give preference to home depositors in the case of a bankruptcy.

Andrew Bailey, who heads the Prudential Regulation Agency, told a Parliamentary committee last month that he would also like to seek an exception to EU rules that in theory allow any bank from the 27-nation bloc to open a London branch. "I do not think that a bank should be able to branch in and the host authority have to accept it come what may," he opined (FT.com, 2014).

There appears to be considerable expense involved in the necessary ICAAP and SREP sections. For a branch with assets of less than $£ 2$ bn the PRA estimates there will be an one-off cost of $£ 525,000$ and annual costs of $£ 150,000$ to convert to a subsidiary. There are also other indirect costs the PRA cannot quantify, such as having to hold more capital in a UK subsidiary, which is a separate legal entity from the parent bank, unlike a branch (BBC News, 2014). The result is, however, expected to be a more stable banking system with more foreign banks investigated and regulated.

The Prudential Regulatory Authority (PRA), which is the UK supervisory authority, requires banks to maintain stable capital management in order to combat serious risks and support their regulatory capital levels on a long-term basis. To that end, banks need to integrate the ICAAP process into every aspect of their risk management and business strategies, with a particular emphasis on stress tests and risk appetite. FSA outlines its regulatory requirements and ICAAP guidelines in the Prudential Sourcebook (Fca.org.uk, 2014).

\section{THE INTERNAL CAPITAL ADEQUACY ASSESSMENT PROCESS AT UK BANKS}

FSA wants to make sure banks conduct detailed assessments of their risk profiles and calculate their internal capital resources. Banks must also be able to demonstrate how regulatory capital requirements will be maintained under stressed conditions for a five-year period. A bank's ICAAP framework must be reviewed and if necessary amended at least once a year. The bank board must approve the findings (Kpmg.at, 2014, p. 34).

Most banks operating in the UK will use the 'Pillar 1 plus' approach when implementing their ICAAP. Under this approach, a bank will measure its capital needs by first defining its Pillar 1 financial requirements as well as Pillar 2 risks, which include interest rate and concentration risks (Bankofengland.co.uk, 2014).

Larger banks, on the other hand, will often use an economic capital model to help define and measure risk. Some will outline in their ICAAP the difference between required regulatory capital and required risk-taking capacity for one year. Both approaches are different. Economic capital models, for instance, accept diversification benefits. However, this is not permitted under regulatory guidelines. If a bank bases its ICAAP on an economic capital model, it must also chart regulatory capital outcomes. By doing so, the bank's regulatory requirements can be based on a 'Pillar 1 plus' approach. The bank needs to prove to FSA that economic capital models are an important part of its business and operational strategies (Kpmg.at, 2014, p. 34). 
THE OVERALL ORGANISATION OF THE SUPERVISORY REVIEW \& EVALUATION PROCESS

A bank must have its ICAAP approved by its board before submitting it to FSA. The submission must detail the bank's ICAAP framework and include a financial summary, along with any relevant background information and business and risk strategies. FSA published submission guidelines in 2007, but the process has drastically changed since then (Bankofengland.co.uk, 2014). FSA will test the efficiency of a bank's ICAAP through a series of on-site and off-site examinations. The regulator will conduct numerous interviews before an on-site visit. The number of interviews will depend on the scope of the bank's business. They can be conducted discretely or incorporated into FSA's risk assessment review (ARROW). FSA will sometimes request an outside examination of a bank's capital calculations and management structure, in accordance with the Financial Services and Markets Act (Kpmg.at, 2014, p. 34)

\section{SREP: MAIN FOCUS}

The supervisory review and evaluation will assess how effectively a bank integrates its ICAAP framework into its risk management strategies and overall governance. These include capital allocation, stress testing, risk assessment, forward capital, and liquidity planning (Bankofengland.co.uk, 2014). After completing its review and evaluation, FSA will issue Individual Capital Guidance (ICG) to the bank. ICG outlines the quality and quantity of capital the bank should have in order to meet Pillar 1 and Pillar 2 capital requirements. If the bank's assessment does not adequately address its risks, FSA may require that the bank apply additional financial requirements. ICG combines the bank's capital regulatory requirements and specific risk add-ons under Pillar 2 (Kpmg.at, 2014, p. 34). FSA rigorously reviews the qualitative and quantitative aspects of the bank's ICAAP framework before calculating its ICG. The regulator will analyse Pillar 1 and 2 risks to determine whether the bank has assembled an adequate five-year capital plan that will be able to withstand a serious economic meltdown.

FSA does not publicly release a lot of information about ICG calculations and methods. However, any Pillar 2 add-on will usually exceed the Pillar 1 minimum by a double-digit percentage, sometimes more depending on the situation. FSA also looks at overall governance and potential weaknesses in the bank's risk management framework. In an effort to help the bank maintain its ICG during periods of stress, the UK regulator will set up a capital planning buffer.

\section{SREP: METHODOLOGICAL FOCUS AREAS}

Risk measurement requirements are outlined in Pillar 1. However, banks must decide whether they will need to maintain more capital under Pillar 2 for situations where Pillar 1 methods do not cover certain risks. Banks are required to identified those risks and calculate how much extra capital they will need to hold (Kpmg.at, 2014, p. 34).

Most banks, in general, will focus on concentration, pension and Interest Rate Risk in the Banking Book (IRRBB) risks and will ensure they have enough available capital to cover those risks. Pension risks take into account life expectancy increases and the vulnerability of asset prices as well as funding risks. Banks are not required to set aside capital for non-quantifiable risks. However, they must show that they have considered these types of risks in their capital plans (Kpmg.at, 2014, p. 34).

Liquidity risks are subjected to a separate assessment process called ILAA (Individual Liquidity Adequacy Assessment), which considers the risks involved if a bank is unable to pay its debts. It also studies highfunding cost risks, which could lead to additional capital costs. Banks need to prepare for situations that might bite into capital reserves. A bank's ILAA report should address both qualitative and quantitative aspects of liquidity risks (Bankofengland.co.uk, 2014). 
Considered valuable management tools, banks are expected to integrate stress and scenario tests into their ICAAP structure. These tests should reflect the scope and complexity of potential risks as well as the business interests of the banks. Banks need to assess how their future earnings, capital resources and CRR would be affected during an economic downturn. They should also examine how a downturn might impact their credit and potential consequences of management action (Kpmg.at, 2014, p. 34).

FSA's so-called 'anchor scenarios' give banks guidance about suitable stress and scenario tests as well as the regulator's expectations. Anchor scenarios could, for example, involve the current condition of the UK's GDP, unemployment and real estate prices. Banks can use anchor scenarios to help evaluate their own scenarios.

The general facets of ICAAP and SREP enforcement are shown in the table below:

\begin{tabular}{|c|c|c|c|c|c|c|}
\hline Countries & $\begin{array}{l}\text { Use Going } \\
\text { and Gone } \\
\text { Concern }\end{array}$ & $\begin{array}{l}\text { Enhanced } \\
\text { Capital } \\
\text { Adequacy } \\
\text { Rules for } \\
\text { Larger } \\
\text { Banks }\end{array}$ & $\begin{array}{l}\text { Enhanced } \\
\text { Leverage } \\
\text { ratio Rules } \\
\text { for Larger } \\
\text { Banks }\end{array}$ & $\begin{array}{l}\text { Covered by } \\
\text { European } \\
\text { Banking } \\
\text { Directive } \\
\text { CRD4 } \\
2013 / 36 / \text { EU }\end{array}$ & $\begin{array}{l}\text { Use } \\
\text { Algorithm }\end{array}$ & $\begin{array}{l}\text { In EU Single } \\
\text { Resolution } \\
\text { Mechanism }\end{array}$ \\
\hline Austria & $\checkmark$ & $\checkmark$ & $\checkmark$ & $\checkmark$ & $\theta$ & $\checkmark$ \\
\hline Belgium & $\checkmark$ & $\checkmark$ & $\checkmark$ & $\checkmark$ & $\theta$ & $\checkmark$ \\
\hline France & $\checkmark$ & $\checkmark$ & $\checkmark$ & $\checkmark$ & $\theta$ & $\checkmark$ \\
\hline Germany & $\checkmark$ & $\checkmark$ & $\checkmark$ & $\checkmark$ & $\theta$ & $\checkmark$ \\
\hline Iceland & $\checkmark$ & $\checkmark$ & $\checkmark$ & $\checkmark$ & $\theta$ & $\checkmark$ \\
\hline Ireland & $\checkmark$ & $\checkmark$ & $\checkmark$ & $\checkmark$ & $\theta$ & $\checkmark$ \\
\hline Italy & $\checkmark$ & $\checkmark$ & $\checkmark$ & $\checkmark$ & $\checkmark$ & $\checkmark$ \\
\hline Luxembourg & $\checkmark$ & $\checkmark$ & $\checkmark$ & $\checkmark$ & $\theta$ & $\checkmark$ \\
\hline Netherlands & $\checkmark$ & $\checkmark$ & $\checkmark$ & $\checkmark$ & $\theta$ & $\checkmark$ \\
\hline Spain & $\checkmark$ & $\checkmark$ & $\checkmark$ & $\checkmark$ & $\theta$ & $\checkmark$ \\
\hline Switzerland & $\checkmark$ & $\checkmark$ & $\checkmark$ & $\theta$ & $\theta$ & $\theta$ \\
\hline United Kingdom & $\checkmark$ & $\checkmark$ & $\checkmark$ & $\checkmark$ & $\theta$ & $\theta$ \\
\hline
\end{tabular}

Table 1: Facets of Investigation and Enforcement

\section{CONCLUSIONS}

The European Council meeting of 28-29 June 2012 marked the starting point of an ambitious project to create a European banking union as part of a collective European effort to resolve the current crisis and build a more resilient policy infrastructure for Europe's financial system (European Council, 2012a). The first step will be the creation of the Single Supervisory Mechanism (SSM), now being finalised following an agreement at the Economic and Financial Affairs Council meeting of 13 December 2012 (ECOFIN, 2012). In its subsequent meeting on 14 December 2012, the European Council outlined a tentative vision for the next steps towards the aim of creating a banking union, which will involve significant legislative work alongside other policy initiatives.

On 17 December 2012, ECB President Draghi stated before the ECON Committee, "the second priority for 2013 from the ECB's perspective is the completion of financial union with the establishment of a single resolution mechanism. The aim of resolution is to deal with non-viable banks through measures that include their orderly winding down and closure while preserving financial stability. Such a mechanism will make it possible for banks to fail in an orderly manner." 
The first step, which the European Council conclusions imply should be completed by March 2013, is centered on the Single Supervisory Mechanism (SSM). In addition to the adoption of the Council regulation establishing the SSM (SSM Regulation; Council, 2012), this includes the adoption of the regulation reforming the European Banking Authority (EBA Regulation 2) to adapt it to the new situation created by the advent of the SSM, as well as the adoption of the Capital Requirements Regulation (CRR3) and its complement the fourth Capital Requirements Directive (CRD4), so that the SSM can implement a harmonised supervisory 'rulebook' based on the Basel III Accord, instead of the currently applicable (and often divergent) national regulations. The operational build-up of the SSM would follow. Its initial phase has already started at the ECB with the cooperation of national supervisors.

One important parameter in this build-up phase is the question of which non-euro area Member States will enter "close cooperation arrangements" that would make them participating members of the SSM. While Sweden and the United Kingdom have indicated they did not consider entering such arrangements in the foreseeable future, other non-Euro area member states still have to make a decision. Another significant operational question is the pace of expansion of the ECB's supervisory staff and the specific arrangements it will establish with national supervisors.

Although the situation in Europe is much more highly integrated than that between Europe and the rest of the world, as this paper has shown the current regulation of the Western European banking system, particularly in terms of the regularity of enforcement and penalty, remains highly fragmented. Regrettably this situation provides plenty of scope for regulatory arbitrage which reduces the effectiveness of fractional reserve policy as enshrined in Basel III. It is imperative that enforcement and penalties are standardised to create a more consistent system. The European Banking directive will to some extent reduce the differences between regulation, although it does little to coalesce enforcement policy and penalty values. In addition the Basel Committee on Banking Supervision (BCBS) is in the process of performing an extensive assessment to determine whether all member jurisdictions have uniformly adopted and implemented the capital requirements under the Basel regulatory framework comprising Basel II, 2.5, and III. The BCBS intends to expand its efforts to cover the monitoring and assessment of the Basel standards relating to liquidity, leverage ratios and systemically important banks (SIBs). To this end it is the Regulatory Consistency Assessment Programme (RCAP) which is designed to monitor the harmonisation of the supervisory systems across member jurisdictions worldwide and identify potential gaps in the Basel regulatory framework (Bafin.de, 2014c). 


\section{REFERENCES}

Acpr.banque-france.fr (2014a) Autorité de contrôle prudentiel et de résolution: Les principes édictés par le Comité de Bâle [Online]. Available at: http://acpr.banque-france.fr/controle-prudentiel/les-types-de-controle/les-principes-edictes-par-le-comitede-bale.html (Accessed: 17 August 2014).

Acpr.banque-france.fr (2014b) Secrétariat Général de l'autorité de Contrôle Prudentiel et de Resolution Direction des Affaires Internationales Service Des Affaires Internationales Banques. Notice - Modalités de Calcul des Ratios Prudentiels dans le cadre de la CRDIV [Online]. Available at: http://acpr.banque-france.fr/fileadmin/user_upload/acp/Communication/Communication_a_la_ profession/2014-notice-modalites-calcul-ratios-prudentiels-cdriv.pdf (Accessed: 17 August 2014).

Acpr.banque-france.fr (2014c) Autorité de contrôle prudentiel et de résolution: Les principes édictés par le Comité de Bâle [Online]. Available at: http://acpr.banque-france.fr/controle-prudentiel/les-types-de-controle/les-principes-edictes-par-le-comitede-bale.html (Accessed 17 August 2014).

Acpr.banque-france.fr (2014d) Autorité de contrôle prudentiel et de résolution: Les principes édictés par le Comité de Bâle [Online]. Available at: http://acpr.banque-france.fr/controle-prudentiel/les-types-de-controle/les-principes-edictes-par-le-comitede-bale.html (Accessed 17 August. 2014).

Agm.db.com (2014) Annual General Meeting 2014 - Deutsche Bank [Online]. Available at: https://agm.db.com/en/docs/ Annual_Financial_Statements_and_Management_Report_Deutsche_Bank_AG_2012.pdf (Accessed: 18 August 2014)

App.bde.es (2014) CEBS Guidelines on Stress Testing (GL32) [Online]. Available at: http://app.bde.es/clf_www/leyes. jsp?tipoEnt=0erid=101434 (Accessed : 19 Aug. 2014).

Bafin.de (2014a) BaFin - Homepage. Available at: http://www.bafin.de/EN/Homepage/homepage_node.html;jsessionid=1E 50DCF1DDD4777A7AC58C8F4744B5E9.1_cid381 (Accessed: 18 August 2014).

Bafin.de. (2014b). BaFin - Expert articles - Basel regulatory framework: BCBS assessing implementation. Available at: http://www bafin.de/SharedDocs/Veroeffentlichungen/EN/Fachartikel/2014/fa_bj_1404_baseler_rahmenwerk_en.html?nn=3698804 \#doc5103532bodyText2 (Accessed: 18 August 2014).

Bafin.de (2014c) BaFin - Homepage. Available at: http://www.bafin.de/EN/Homepage/homepage_node.html;jsessionid=9A 2BC8D9261D8003500BFE949CA1F5FF.1_cid372 (Accessed : 19 August 2014).

Banco de España (2014) The Banco de España Supervisory Model, 2011 [Online]. Available at: http://www.bde.es/f/webbde/ COM/Supervision/funciones/Ficheros/en/Banco_de_Es pana_supervisory_model_clean.pdf (Accessed: 19 August 2014).

Bankofengland.co.uk (2014) Bank of England [Online]. Available at: http://www.bankofengland.co.uk/pra/Documents / publications/policy/2013/icaapss513.pdf (Accessed: 19 August 2014).

Bankofireland.ie (2014) Bank of Ireland - For small steps, for big steps, for life. Available at: http:/ / www.bankofireland.ie (Accessed: 29 August 2014)

Basel.int (2014) Basel Convention > Countries > Agreements. Available at: http:/ /www.basel.int/Countries/Agreements/ tabid/1482/Default.aspx (Accessed 17 August 2014)

Cbfa.be (2014) CBFA [Online]. Available at: http://www.cbfa.be/eng/index.asp (Accessed: 17 August 2014)

Cssf.lu (2014) Home: Commission de Surveillance du Secteur Financier (CSSF) [Online]. Available at: http://www.cssf.lu/fileadmin/ files/Publications/Rapports_ponctuels/Etude_impact_2011.pdf (Accessed: 19 August 2014).

Dnb.nl (2014a) De Nederlandsche Bank [Online]. Available at: http://www.dnb.nl/en/binaries/DNB\%20Supervisory\%20 Strategy\%202010-2014_tcm47-238092.pdf (Accessed: 19 August 2014).

Dnb.nl (2014b) De Nederlandsche Bank [Online]. Available at: http://www.dnb.nl/en/publications/dnb-publications/ newsletters/nieuwsbrief-banken/nieuwsbrief-banken-februari-2014/index.jsp (Accessed: 19 August 2014).

Dnb.nl (2014c) De Nederlandsche Bank.\# DNB Supervisory Strategy 2010 - 2014 [Online]. Available at: http://www.dnb.nl/en/ binaries/DNB\%20Supervisory\%20Strategy\%202010-2014 tcm47-238092.pdf (Accessed: 19 August 2014).

Esrb.europa.eu (2014) European Systemic Risk Board [Online]. Available at: https:/ /www.esrb.europa.eu/mppa/cbmd/shared/ pdf/Spain/2013-12-09_Guidelines_ICAAP.pdf?d046183d980f1ec6312782e5c2d5d0bf (Accessed: 19 August 2014).

Europa.eu (2014) EUROPA - PRESS RELEASES - Press release - Midday Express of 2013-07-16 [Online]. Available at: http:// europa.eu/rapid/press-release_MEX-13-0716_en.htm?locale=en (Accessed : 26 May. 2014).

Fca.org.uk (2014) Integrated Prudential sourcebook (PRU) - Financial Conduct Authority [Online]. Available at: http://www.fca.org. uk/your-fca/documents/waivers/integrated-prudential-sourcebook-waivers (Accessed: 19 August 2014). 
Financial Times (2014) Britain tightens grip on foreign banks [Online]. Available at: http://www.ft.com/intl/cms/ s/0/3edf0b3a-41ef-11e2-979e-00144feabdc0.html (Accessed: 19 August 2014).

Fma.gv.at (2014) BANKING SUPERVISION IN AUSTRIA. Available at: http://www.fma.gv.at/typo3conf/ext/dam_download/ secure.php?u=0erfile=3739ert=1405723234erhash=155b8018a93d022e3b6c7206bb7cea86 (Accessed: 17 August 2014).

Google Books (2014a) Austria: Publication of Financial Sector Assessment Program Documentation Detailed Assessment of Basel Core Principles for Effective Banking Supervision [Online]. Available at: http://books.google.cz/books?id=7kPgAgAAQBAJerpg=PT20 8erlpg=PT208erdq=srep+in+Austriaersource=blerots=di5GXZEtZQersig=ahGuCYD4dSihOj9Mi93YYU4N6Hwerhl=eners $\mathrm{a}=$ Xerei=ekCDU8rBLuyB7Qae8oCADgerved=0CEUQ6AEwBQ\#v=onepageerq=srep\%20in\%20Austriaef ffalse (Accessed: 26 May 2014).

Google Books (2014b) Belgium: Detailed Assessment of Compliance with the Basel Core Principles for Effective Banking Supervision [Online]. Available at: http://books.google.cz/books?id=rNbzOiiUT7ECerpg=PA76erlpg=PA76erdq=belgium+|CAAPersour ce=blerots=eyjhmp8GlCersig=ewZDml4QvR3A_Qhcsfw9VMrewE4erhl=enersa=Xerei=oUeDU_X_EKup7Qabz4CgDwerv ed=0CDgQ6AEwAw\#v=onepageerq=belgium\%20ICAAPerf=false (Accessed: 26 May 2014)

Google Books (2014c) Ireland: Detailed Assessment of Observance of Basel Core Principles for Effective Banking Supervision [Online]. Available at: http://books.google.cz/books?id=QDzOAwAAQBAJerpg=PA136elpg=PA136erdq=ICAAP+ireland+frequenc yersource=blerots=G5D05fSmtgersig=Cj9mdhdGIXkX8oVi8wTIE3GyL3Merhl=csersa=Xerei=3fn1U8-xLcP4yQPKoYHoB werved=0CEEQ6AEwBA\#v=onepageerq=ICAAP\%20ireland\%20frequencyerf=false (Accessed: 21 August 2014).

IMF (2014) Belgium: Detailed Assessment of Compliance with the Basel Core Principles for Effective Banking Supervision. Available at: http://www.imf.org (Accessed: 17 August 2014).

Imf.org (2014) IMF -- International Monetary Fund Home Page. Available at: http:/ /www.imf.org/external/pubs/ft/scr/2013/ cr13354.pdf (Accessed: 18 August 2014).

Kpmg.at (2014) Home - KPMG. Available at: http://www.kpmg.at/home.htmlhttps://www.kpmg.at/uploads/media/ KPMG_Study_on_ICAAP_In_Europe_May_2011_01.pdf p14 (Accessed: 17 August 2014).

Oenb.at (2014) Supervisory Responsibilities in Austria [Online]. Available at: http://www.oenb.at/en/Financial-Stability/ Banking-Supervision/Supervisory-Responsibilities-in-Austria.html (Accessed: 17 August 2014).

Putnis, J. (ed.) (2014) The Banking Regulation Review [Online]. Available at: http://www.ehp.lu/uploads/media/Banking Regulation_Review_Luxembourg_2013.pdf (Accessed: 26 May 2014).

PwC (2014) PwC Luxembourg [Online]. Available at: PwC, (2014). PwC Luxembourg. [online] Available at: http://www.pwc.lu (Accessed 19 August 2014).

Roldan, J. (2014) Implemenation of Basel II. Basel: Bank of International Settlements. Available at: http:/ / www.bde.es/f/webbde/ GAP/Secciones/SalaPrensa/IntervencionesPublicas/regula140907e.pdf (Accessed: 19 August 2014).

Sedlabanki.is (2014) Seðlabanki Ílands [Online]. Available at: http://www.sedlabanki.is/library/Skr\%C3\%A1arsafn/ Al\%C3\%BEj\%C3\%B3\%C3\%BOasvi\%C3\%BO/Statment\%20by\%20an\%20IMF\%20Mission\%20to\%20lceland.pdf (Accessed: 22 August 2014).

Sommer, D. and Spielberg, H. (2014) ICAAP in Europe: Moving in different directions... / KPMG / CH. [Online]. Kpmg.com. Available at: http://www.kpmg.com/ch/en/library/articles-publications/pages/icaap-in-europe.aspx (Accessed: 26 May 2014).

Str-act! Agentur für interaktives Marketing (2014) FMA: Financial Market Stability Board [Online]. Available at: http:/ /www. fma.gv.at/en/about-the-fma/responsibilities/financial-market-stability-board.html (Accessed: 17 August 2014).

Woschnagg, E. (2008) ICAAP Implementation in Austria's Major Banks. Financial Stability Report [Online]. (16). Available at: http:// econpapers.repec.org/article/onboenbfs/y_3a2008_3ai_3a16_3ab_3a2.htm (Accessed: 26 May 2014).

\section{TABLES}

TABLE 1: Draper, T. (2014) Facets of Investigation Enforcement. 